\title{
Fusion of platelet-derived growth factor receptor $\beta$ to CEV14 gene in chronic myelomonocytic leukemia: A case report and review of the literature
}

\author{
SHENG-LAN GONG, MENG-QIAO GUO, GU-SHENG TANG, CHUN-LING ZHANG, \\ HUI-YING QIU, XIAO-XIA HU and JIAN-MIN YANG \\ Department of Hematology, Changhai Hospital, Second Military Medical University, Shanghai 200433, P.R. China
}

Received January 28, 2015; Accepted September 14, 2015

DOI: $10.3892 / \mathrm{ol} .2015 .3949$

\begin{abstract}
Myeloid tumor possessing platelet-derived growth factor receptor $\beta$ (PDGFR $\beta$ ) gene rearrangement is a rare hematological malignancy, which presents with typical characteristics of myeloid proliferation disorders and eosinophilia. In the present study, an elderly chronic myelomonocytic leukemia patient was diagnosed with chromosome rearrangement. Fluorescence in situ hybridization (FISH) was conducted with a PDGFR $\beta$ isolate probe, and gene translocation between PDGFR $\beta$ on chromosome 5 and genes on the chromosomes of group D (13-15) was detected. Karyotype analysis revealed a chromosome 5 break, and PDGFR $\beta$-thyroid hormone receptor interactor 11 (CEV14) gene fusion was confirmed via reverse transcription-polymerase chain reaction (RT-PCR), which additionally revealed the chromosome rearrangement $\mathrm{t}(5 ; 14)(\mathrm{q} 33 ; \mathrm{q} 32)$. Due to the correlation between PDGFR $\beta$-CEV14 expression and effectiveness of treatment with tyrosine kinase inhibitors, this fusion gene is considered to be an oncogene. In the present study, an elderly patient was diagnosed with a myeloid tumor associated with the fusion gene PDGFR $\beta$-CEV14, using the methods of FISH and RT-PCR. These methods were confirmed to be of significant value in improving diagnosis, guiding treatment and increasing the cure rate of patients, due to their ability to detect multiple rearrangement genes associated with PDGFR $\beta$ in myelodysplastic and myeloproliferative neoplasms.
\end{abstract}

\section{Introduction}

Platelet-derived growth factor receptors (PDGFRs), which are part of the class III receptor tyrosine kinase family, exert stimulatory effects on c-Kit, Fms-like tyrosine kinase 3 and

Correspondence to: Mr. Jian-Min Yang, Department of Hematology, Changhai Hospital, Second Military Medical University, 168 Changhai Road, Yangpu, Shanghai 200433, P.R. China

E-mail: yangjianmin@csco.org.cn

Key words: chronic myelomonocytic leukemia, chromosome rearrangement, platelet-derived growth factor receptor $\beta$, gene fusion macrophage colony-stimulating factor receptors (1). PDGFRs consist of an extracellular ligand-binding region, a transmembrane domain and an intracellular kinase domain (2). Ligand binding induces dimerization and autophosphorylation of the receptor, facilitating binding and activation of various cytoplasmic signal transduction molecules (3). In this way, multiple signaling pathways are initiated, resulting in cell proliferation (4).

Myeloid tumors possessing PDGFR $\beta$ gene rearrangement are a rare hematological malignancy, which present with typical characteristics, including myeloid proliferation disorders and eosinophilia. Chronic myelomonocytic leukemia (CMML) is a poorly defined, heterogeneous clinicopathological syndrome that exhibits myelodysplastic and myeloproliferative features (5), and there are no specific therapeutic strategies for treating patients with CMML. According to laboratory and ancillary tests, cytogenetic abnormalities occur in $\sim 30 \%$ of CMML patients, however, there are no consistently recurring chromosomal translocations that can be depended upon for diagnostic criteria, and the incidence of chromosomal translocation in CMML patients is only $1-2 \%$ (6).

To determine the role of PDGFR $\beta$ gene rearrangement in the pathogenesis of CMML, the current study reports a case of CMML associated with a $\mathrm{t}(5 ; 14)(\mathrm{q} 33 ; \mathrm{q} 32)$ fusion gene using fluorescence in situ hybridization (FISH) and reverse transcription-polymerase chain reaction (RT-PCR). The patient was effectively treated with imatinib, and the relevant literature was reviewed.

\section{Case report}

Patient. A patient with CMML was diagnosed, using immunophenotyping and morphological methods, according to the World Health Organization (WHO) classification of tumors of hematopoietic and lymphoid tissues (7).

Routine karyotype analysis. A bone marrow sample was collected from the patient (heparin lithium was used as an anticoagulant), and cultured in Dulbecco's modified Eagle's medium with $20 \%$ fetal bovine serum using the direct and short-term culture methods (8). Termination of culture was performed following culturing in colchamine for $1 \mathrm{~h}$, and cells 


\section{K}

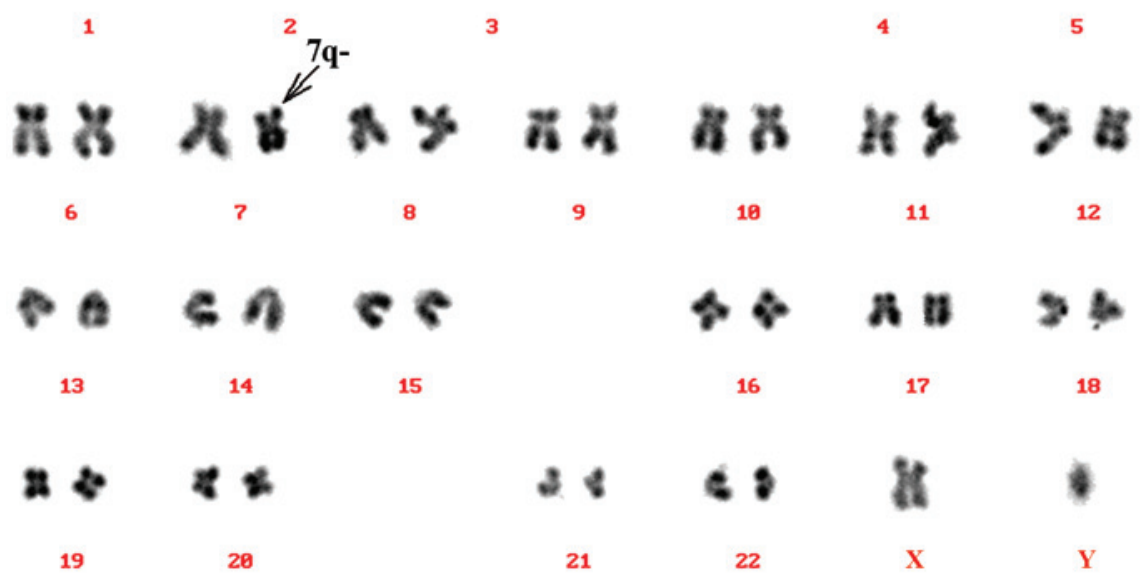

Figure 1. Karyotype analysis revealed a break in the long arm of chromosome 5. Derivative chromosomes are indicated by arrowheads.
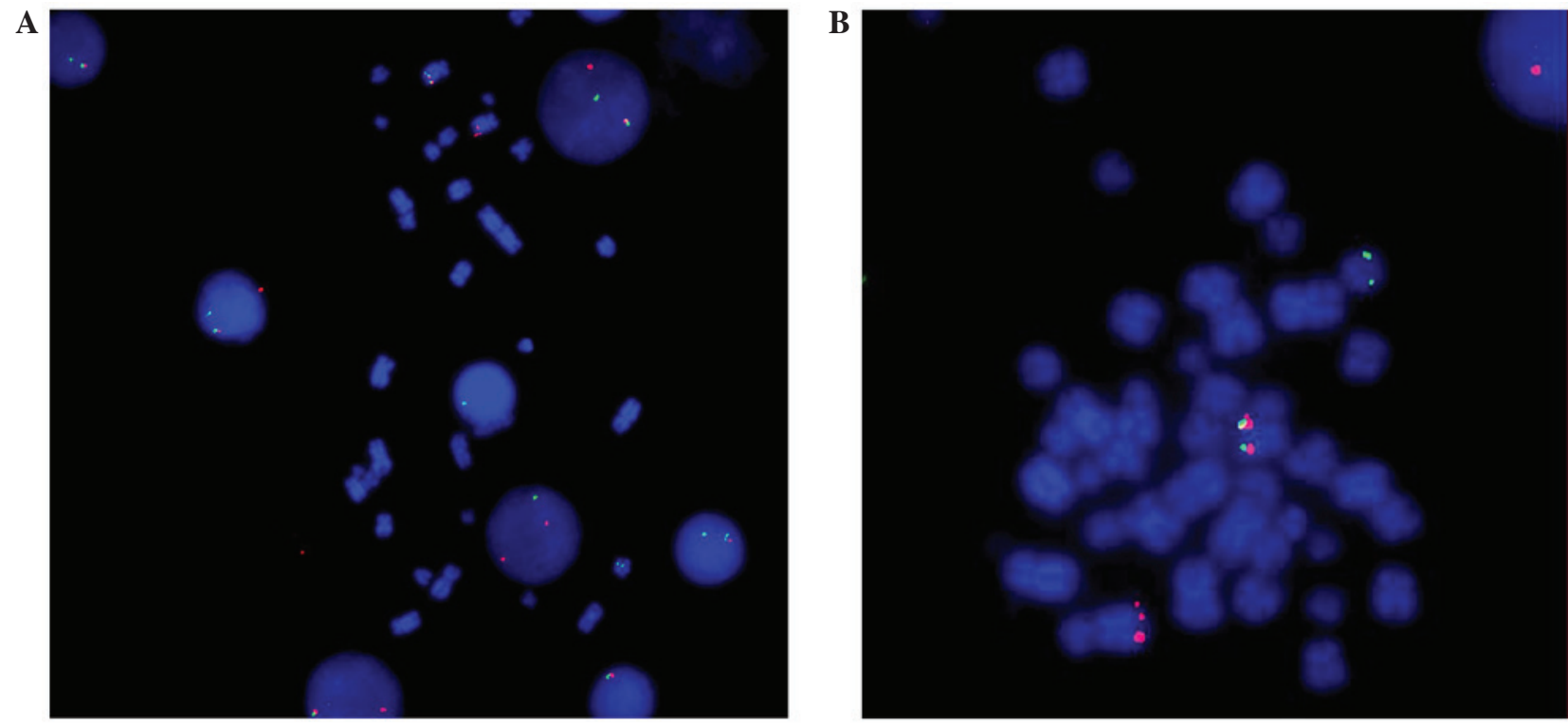

Figure 2. Gene rearrangement of PDGFR $\beta$ was detected via fluorescence in situ hybridization. (A) Red and green fluorescence indicated the PDGFR $\beta$ gene rearrangement in interphase cells. (B) Gene isolation signals were located on chromosomes 5 and 14 . PDGFR $\beta$, platelet derived growth factor receptor $\beta$. Magnification, x1,000.

were subsequently fixed in a solution of methanol and glacial acetic acid (methanol:glacial acetic acid, 3:1). Following fixing, cells were collected and chromosome karyotype was analyzed after conventional reverse-banding (9). The remaining cells were stored in fresh fixative and preserved at $20^{\circ} \mathrm{C}$. Chromosomes were analyzed according to standard procedures (10) and the karyotype was classified according to 'An International System for Human Cytogenetic Nomenclature (ISCN 2009)' (11). The results of karyotype analysis revealed a break in chromosome 5 (Fig. 1).

FISH. PDGFR $\beta$ isolate probe (Cytocell, Cambridge, UK), which was complementary to the PDGFR $\beta$ gene, was applied to the cells, and tagged with green and orange spectroscopy tags. The methods used were previously described by Guo et al (12). Positive abnormal signals, including red and green fluorescence, were detected via FISH. This indicated PDGFR $\beta$ gene rearrangement of cells during interphase (Fig. 2A). Fig. 2B indicates the gene isolation signals, which were located on chromosomes 5 and 14 .

$R T$-PCR processing. The thyroid hormone receptor interactor 11 (CEV14)-PDGFR $\beta$ fusion gene was amplified via PCR, following the protocol described by Huang et al (13). Samples were then analyzed for the presence of the fusion gene product. Briefly, total RNA $(1 \mu \mathrm{g})$ was extracted using Trizol reagent (Invitrogen; Thermo Fisher Scientific, Waltham, MA, USA). Complementary DNA (cDNA; $1 \mu \mathrm{l}$ ) was synthesized using the 


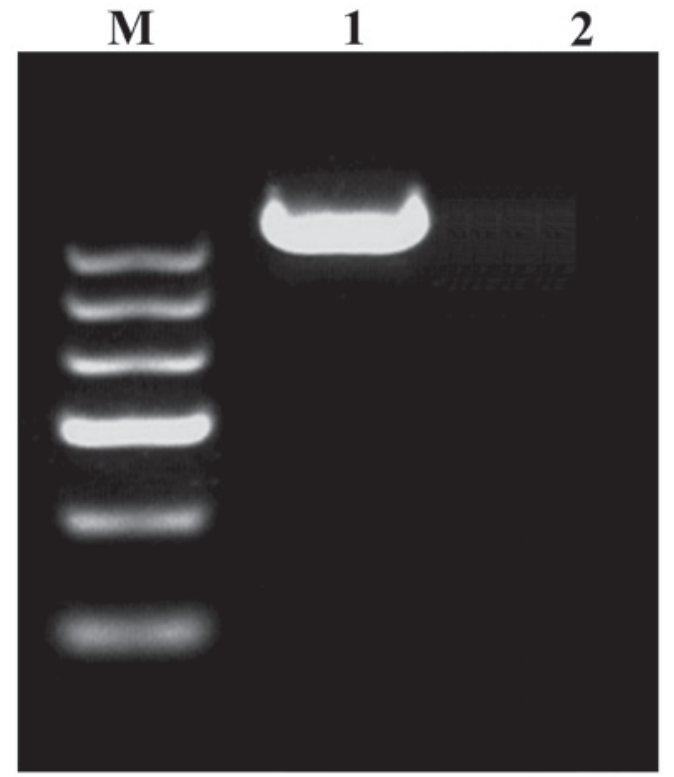

Figure 3. CEV14-platelet-derived growth factor receptor $\beta$ fusion gene was detected using reverse transcription-polymerase chain reaction. Lanes: M, DNA marker; 1, patient sample; 2, negative control sample from a healthy individual.

Takara RNA PCR kit (Takara Bio, Inc., Otsu,Japan) according to the manufacturer's instructions. According to the reported translocated genes on chromosome 14, CEV14 (14q32) (14), coiled-coil domain containing 88C (KIAA1509) (14q32) (15) and ninein (GSK3B interacting protein) (NIN) (14q24) (16) primers were selected and designed. The primers utilized were as follows: PDGFR $\beta$ forward, 5'-GTGGTGAGCACA CTGCGTCTG-3' and reverse, 5'-GTAACGTGGCTTCTT CTGCCA-3'; CEV14 forward, 5'-CGCTGCAGCTTTCTG TCTCTCAGGAACAAG-3' and reverse, 5'-GCGAGGAGC CAAACGGATTTACATCTGTAA-3'; KIAA1509 forward, 5'-CTTATTTGGGATGGAGCCCT-3' and reverse, 5'-CCG GGACACAGATAAGA-3'; NIN forward, 5'-TACCAAGAA CAGCATTCACCAGGCG-3' and reverse, 5'-GCGGCAGTG CAGGGTACTACAAGAC-3'. The PCR cycling conditions used was as follows: 30 cycles of $94^{\circ} \mathrm{C}$ for $1 \mathrm{~min}, 45^{\circ} \mathrm{C}$ for $1 \mathrm{~min}$ and $72^{\circ} \mathrm{C}$ for $1 \mathrm{~min}$. PCR products were electrophoresed on $2 \%$ agarose gels and stained with ethidium bromide. As indicated in Fig. 3, the CEV14-PDGFR $\beta$ fusion gene was detected using RT-PCR.

Bone marrow morphology and immunophenotyping. A bone marrow smear revealed serious granulopoiesis, monocytosis, accompanying myelodysplasia and an increase in bone marrow blast cell and promonocyte numbers. Hemogram analysis revealed increased monocytic hyperplasia, progranulocytes and promonocytes. Immunophenotyping results confirmed the diagnosis of chronic myelomonocytic leukemia.

\section{Discussion}

The WHO classification of tumors of hematopoietic and lymphoid tissues (2008) defined a novel category for myeloid and lymphoid neoplasms associated with eosinophilia and abnormalities of PDGFR $\alpha$, PDGFR $\beta$ or fibroblast growth receptor 1 (17). Myelodysplastic/myeloproliferative neoplasms (MDS/MPN), characterized by dyshematopoiesis and myeloproliferation, may be classified into several types: CMML, atypical chronic myelogenous leukemia, juvenile myelomonocytic leukemia and MDS/MPN-unclassifiable (18). MDS/MPN occurs primarily in adult men with normal chromosome karyotypes, and the underlying pathogenesis remains to be fully elucidated (6).

Myeloid neoplasms associated with rearrangement of PDGFR $\beta$, demonstrate a PDGFR $\beta$ fusion gene on chromosome 5q31-33, and are characterized by fever, weakness, hepatosplenomegaly and, in certain cases, cardiac damage and skin infiltration (19). This type of neoplasm possesses a variety of hematological symptoms, including eosinophilia, monocytosis and characteristics of systemic mastocytosis, for example bone marrow mastocytosis and abnormal expression of cluster of differentiation 25 (17).

The most common chromosome translocation that accompanies PDGFR $\beta$ gene rearrangement is $\mathrm{t}(5 ; 12)(\mathrm{q} 33 ; \mathrm{p} 13)(20)$. Golub et al (21) confirmed that the juxtaposition of the PDGFR $\beta$ gene on chromosome 5 and the ets variant 6 (TEL) gene on the short arm of chromosome 12, which formed the TEL-PDGFR $\beta$ fusion gene, sequentially activated the PDGFR $\beta$ tyrosine kinase. This enhanced cell proliferation and inhibited apoptosis, thus generating tumor deterioration and metastasis, through the activation of multiple signaling pathways, ultimately leading to the formation of a myeloproliferative disorder $(22)$. The $\mathrm{t}(5 ; 14)$ chromosome translocation detected in the present study is rare and, to the best of our knowledge, has been reported in the relevant literature $<10$ times $(14,23-31)$. The $t(5 ; 14)$ chromosome translocation has been observed to typically be present in T-cell acute lymphoblastic leukemia (T-ALL) $(24,26)$. The partner genes of PDGFR $\beta$ include human homeobox 11-like 2 (Hox11L2) $(23,24,28-30)$ and CEV14 $(14,31)$. Previous studies have revealed that the translocation of chromosomes 5 and 14 is associated with transcriptional activation of the Hox11L2 gene (24), as well as genetic recombination of RAN binding protein 17-T-cell leukemia, homeobox protein 3 and B-cell lymphoma 11B (26). In the relevant literature, CEV14-PDGFR $\beta$ fusion gene on $\mathrm{t}(5 ; 14)(\mathrm{q} 33 ; \mathrm{q} 32)$ has been identified in two reported cases: One T-ALL (31) and one acute myeloid leukemia case (14). The latter of these cases demonstrated that CEV14-PDGFR $\beta$ was capable of accelerating the formation of leukemia, and thus may be a direct cause of cancer formation (14). Furthermore, the presence of the CEV14-PDGFR $\beta$ fusion gene in T-ALL was concluded to be associated with a high rate of relapse (31). To the best of our knowledge, the present study is the first to report a case of CMML associated with $\mathrm{t}(5 ; 14)$ (q33;q32), and further studies may be required in order to investigate the association between the chromosome translocation and an increased recurrence rate of CMML.

Myeloid tumors associated with PDGFR $\beta$ gene rearrangement have been a significant research focus, due to their susceptibility to drug therapy and high rate of complete remission (20,32-35). With the exception of protein kinase cyclic guanosine monophosphate-dependent type II-PDGFR $\beta$, PDGFR $\beta$ fusion genes are capable of forming dimers with receptors, which leads to autophosphorylation, and thus 
induces the persistent activation of tyrosine kinases. Imatinib, a tyrosine kinase inhibitor, is typically used to treat myeloid tumors exhibiting PDGFR $\beta$ fusion, in order to achieve sustained remission $(20,32,36)$. Due to potential side-effects, including adverse drug reactions following multiple administrations, a limited daily dosage of imatinib has been recommended (37). The serum creatinine value of the patient in the present study gradually increased following treatment with imatinib (400 mg/day) for 4 days, thus the daily dosage of imatinib was reduced to $300 \mathrm{mg} /$ day. On day 5 of treatment, percussive pain over the left renal region and hematuria were detected, and kidney stones were diagnosed by ultrasound. Therefore, a reduced dosage of imatinib was subsequently administered (100 mg/day), and kidney-sparing surgery was successfully performed in order to prevent deterioration of the patient. As symptoms were controlled by using a lower dose of imatinib, low dosages of imatinib may be an effective therapy for MDS/MPN associated with PDGFR $\beta$-CEV14, however the long-term curative effects of this therapeutic strategy require further investigation.

Detection of PDGFR $\beta$-associated fusion genes in individual patients appears to be necessary for definitive diagnosis, guiding treatment, predicting prognosis and monitoring minimal residual disease in MDS/MPN. In the present study, an elderly patient was diagnosed with a myeloid tumor associated with the PDGFR $\beta$-CEV14 fusion gene, using the methods of FISH and RT-PCR. These methods were therefore proven to be of significant value in improving diagnosis, guiding treatment and increasing the cure rate of MDS/MPN patients, via the detection of multiple genes exhibiting rearrangement, which are associated with PDGFR $\beta$ in MDS/MPN.

\section{Acknowledgements}

The present study was supported by the National Natural Science Foundation of China (Beijing, China; grant no. 81200383).

\section{References}

1. Reilly JT: Class III receptor tyrosine kinases: Role in leukaemogenesis. Br J Haematol 116: 744-757, 2002.

2. Heldin $\mathrm{CH}$, Ostman A and Rönnstrand L: Signal transduction via platelet-derived growth factor receptors. Biochim Biophys Acta 1378: F79-F113, 1998.

3. Donovan J, Shiwen X, Norman J and Abraham D: Platelet-derived growth factor alpha and beta receptors have overlapping functional activities towards fibroblasts. Fibrogenesis Tissue Repair 6: 10, 2013.

4. Demoulin JB, Enarsson M, Larsson J, Essaghir A, Heldin CH and Forsberg-Nilsson K: The gene expression profile of PDGF-treated neural stem cells corresponds to partially differentiated neurons and glia. Growth Factors 24: 184-196, 2006.

5. Steensma DP, Tefferi A and Li CY: Splenic histopathological patterns in chronic myelomonocytic leukemia with clinical correlations: reinforcement of the heterogeneity of the syndrome. Leuk Res 27: 775-782, 2003.

6. Emanuel PD: Juvenile myelomonocytic leukemia and chronic myelomonocytic leukemia. Leukemia 22: 1335-1342, 2008.

7. Vardiman JW: The World Health Organization (WHO) classification of tumors of the hematopoietic and lymphoid tissues: an overview with emphasis on the myeloid neoplasms. Chem Biol Interact 184: 16-20, 2010.

8. Finelli P, Giardino D, Rizzi N, Buiatiotis S, Virduci T, Franzin A, Losa M and Larizza L: Non-random trisomies of chromosomes 5, 8 and 12 in the prolactinoma sub-type of pituitary adenomas: conventional cytogenetics and interphase FISH study. Int J Cancer 86: 344-350, 2000
9. Verma RS and Dosik H: The value of reverse banding in detecting bone marrow chromosomal abnormalities: Translocation between chromosomes 1,9 , and 22 in a case of chronic myelogenous leukemia (CML). Am J Hematol 3: 171-175, 1977.

10. Claussen U, Michel S, Mühlig P, Westermann M, Grummt UW, Kromeyer-Hauschild K and Liehr T: Demystifying chromosome preparation and the implications for the concept of chromosome condensation during mitosis. Cytogenet Genome Res 98: 136-146, 2002.

11. Shaffer LG, Slovak ML and Campbell LJ(eds): ISCN 2009: An International System for Human Cytogenetic Nomenclature (2009): Recommendations of the International Standing Committee on Human Cytogenetic Nomenclature. 1st edition. S Karger AG, Switzerland, 2009.

12. Guo B, Da WM, Han XP, Zhao DD, Jin HJ, Wang K and Tang JY: Study of BCR-ABL gene rearrangement by dual-color-dual-fusion fluorescence in situ hybridization on acute lymphoblastic leukemia patients. Chin J Lab Med 10: 902-905, 2006.

13. Huang W, Cao Q and Lu Y: Detection on BCR-ABL fusion gene in Ph1 chromosome positive leukemia by 'nested' retrotranscriptase/polymerase chain reaction. Chin J Hema 13: 183-186, 1992 (In Chinese).

14. Abe A, Emi N, Tanimoto M, Terasaki H, Marunouchi T and Saito H: Fusion of the platelet-derived growth factor receptor $\beta$ to a novel gene CEV14 in acute myelogenous leukemia after clonal evolution. Blood 90: 4271-4277, 1997.

15. Levine RL, Wadleigh M, Sternberg DW, Wlodarska I, Galinsky I, Stone RM, DeAngelo DJ, Gilliland DG and Cools J: KIAA1509 is a novel PDGFRB fusion partner in imatinib-responsive myeloproliferative disease associated with a $\mathrm{t}(5 ; 14)(\mathrm{q} 33 ; \mathrm{q} 32)$. Leukemia 19 : 27-30, 2005.

16. Vizmanos JL, Novo FJ, Román JP, Baxter EJ, Lahortiga I, Larráyoz MJ, Odero MD, Giraldo P, Calasanz MJ and Cross NC: NIN, a gene encoding a CEP110-like centrosomal protein, is fused to PDGFRB in a patient with a $\mathrm{t}(5 ; 14)(\mathrm{q} 33 ; \mathrm{q} 24)$ and an imatinib-responsive myeloproliferative disorder. Cancer Res 64: 2673-2676, 2004.

17. Bain BJ (ed): Leukaemia Diagnosis. 4th edition. Wiley-Blackwell, Chichester, pp68-73, 2010.

18. Provan A, Baglin T, Dokal I and de Vos J (eds): Myelodysplasia. In: Oxford Handbook of Clinical Haematology. 3rd edition. Oxford University Press, Oxford, pp244-247, 2009.

19. Walz C, Metzgeroth G, Schoch C, Haferlach T, Hehlmann R, Hochhaus A, Cross NCP and Reiter A: Characterization of two new imatinib-responsive fusion genes generated by disruption of PDGFRB in eosinophilia-associated chronic myeloproliferative disorders. Blood 108: 667, 2006.

20. Apperley JF, Gardembas M, Melo JV, Russell-Jones R, Bain BJ, Baxter EJ, Chase A, Chessells JM, Colombat M, Dearden CE, et al: Response to imatinib mesylate in patients with chronic myeloproliferative diseases with rearrangements of the platelet-derived growth factor receptor beta. N Engl J Med 347: 481-487, 2002.

21. Golub TR, Barker GF, Lovett M and Gilliland DG: Fusion of PDGF receptor beta to a novel ets-like gene, tel, in chronic myelomonocytic leukemia with $\mathrm{t}(5 ; 12)$ chromosomal translocation. Cell 77: 307-316, 1994.

22. Ritchie KA, Aprikyan AA, Bowen-Pope DF, Norby-Slycord CJ, Conyers S, Bartelmez S, Sitnicka EH and Hickstein DD: The Tel-PDGFRbeta fusion gene produces a chronic myeloproliferative syndrome in transgenic mice. Leukemia 13: 1790-1803, 1999.

23. Hélias C, Leymarie V, Entz-Werle N,Falkenrodt A, Eyer D, Costa JA, Cherif D, Lutz P and Lessard M: Translocation t(5;14)(q35;q32) in three cases of childhood T cell acute lymphoblastic leukemia: A new recurring and cryptic abnormality. Leukemia 16: 7-12, 2002.

24. Bernard OA, Busson-LeConiat M,Ballerini P, et al: A new recurrent and specific cryptic translocation, $\mathrm{t}(5 ; 14)(\mathrm{q} 35 ; \mathrm{q} 32)$, is associated with expression of the Hox11L2 gene in T acute lymphoblastic leukemia. Leukemia 15: 1495-1504, 2001.

25. Haider S, Matsumoto R, Kurosawa N, et al: Molecular characterization of a novel translocation $\mathrm{t}(5 ; 14)(\mathrm{q} 21 ; \mathrm{q} 32)$ in a patient with congenital abnormalities. J Hum Genet 51: 335-340, 2006.

26. Su XY, Della-Valle V, Andre-Schmutz I, et al: HOX11L2/TLX3 is transcriptionally activated through T-cell regulatory elements downstream of BCL11B as a result of the $\mathrm{t}(5 ; 14)(\mathrm{q} 35 ; \mathrm{q} 32)$. Blood 108: 4198-4201, 2006.

27. Berger R, Dastugue N, Busson M, Van Den Akker J, Pérot C, Ballerini P, Hagemeijer A, Michaux L, Charrin C, Pages MP, et al; Groupe Français de Cytogénétique Hématologique (GFCH): $\mathrm{t}(5 ; 14) / H O X 11 \mathrm{~L} 2$-positive T-cell acute lymphoblastic leukemia. A collaborative study of the Groupe Français de Cytogénétique Hématologique (GFCH). Leukemia 17: 1851-1857, 2003. 
28. van Zutven LJ, Velthuizen SC, Wolvers-Tettero IL, van Dongen JJ, Poulsen TS, MacLeod RA, Beverloo HB and Langerak AW: Two dual-color split signal fluorescence in situ hybridization assays to detect $\mathrm{t}(5 ; 14)$ involving HOX11L2 or CSX in T-cell acute lymphoblastic leukemia. Haematologica 89: 671-678, 2004.

29. Nagel S, Scherr M, Kel A, Hornischer K, Crawford GE, Kaufmann M, Meyer C, Drexler HG and MacLeod RA: Activation of TLX3 and NKX2-5 in t(5;14)(q35;q32) T-cell acute lymphoblastic leukemia by remote 3'-BCL11B enhancers and coregulation by PU.1 and HMGA1. Cancer Res 67: 1461-1471, 2007.

30. Cavé H, Suciu S, Preudhomme C, Poppe B, Robert A Uyttebroeck A, Malet M, Boutard P, Benoit Y, Mauvieux L, et al; EORTC-CLG: Clinical significance of HOX11L2 expression linked to $\mathrm{t}(5 ; 14)(\mathrm{q} 35 ; \mathrm{q} 32)$, of HOX11 expression, and of SIL-TAL fusion in childhood T-cell malignancies: Results of EORTC studies 58881 and 58951. Blood 103: 442-450, 2004.

31. Shi HT, Zhou F, Hou J, Wei W, Guo LP and Zhang YX: A case of T-cell acute lymphpoblastic leukemia with translocation $\mathrm{t}(5 ; 14)$ (q33; q32). J Chin Hematol 06: 800, 2013 (In Chinese).

32. Wilkinson K, Velloso ER, Lopes LF, Lee C, Aster JC, Shipp MA and Aguiar RC: Cloning of the $t(1 ; 5)(q 23 ; q 33)$ in a myeloproliferative disorder associated with eosinophilia: Involvement of PDGFRB and response to imatinib. Blood 102: 4187-4190, 2003.
33. Baxter EJ, Kulkarni S, Vizmanos JL, Jaju R, Martinelli G, Testoni N, Hughes G, Salamanchuk Z, Calasanz MJ, Lahortiga I, et al: Novel translocations that disrupt the platelet-derived growth factor receptor beta (PDGFRB) gene in BCR-ABL-negative chronic myeloproliferative disorders. Br J Haematol 120: 251-256, 2003.

34. Cross NC and Reiter A: Tyrosine kinase fusion genes in chronic myeloproliferative diseases. Leukemia 16: 1207-1212, 2002.

35. Salaroli A, Loglisci G, Serrao A, Alimena G and Breccia M: Fasting glucose level reduction induced by imatinib in chronic myeloproliferative disease with TEL-PDGFR $\beta$ rearrangement and type 1 diabetes. Ann Hematol 91: 1823-1824, 2012.

36. Gallagher G, Horsman DE, Tsang P and Forrest DL: Fusion of PRKG2 and SPTBN1 to the platelet-derived growth factor receptor beta gene (PDGFRB) in imatinib-responsive atypical myeloproliferative disorders. Cancer Genet Cytogenet 181: 46-51, 2008.

37. Tanaka MF, Kantarjian H, Cortes J, Ohanian M and Jabbour E: Treatment options for chronic myeloid leukemia. Expert Opin Pharmaco 13: 815-828, 2012. 